\title{
Pengoreksi Nada Menggunakan Mikrokontroler untuk Meningkatkan Kualitas Suara pada Biola
}

\author{
Danu Kusuma Wardhana*1, Tri Kuntoro Priyambodo ${ }^{2}$ \\ ${ }^{1}$ Prodi Elektronika dan Instrumentasi, Jurusan Ilmu Komputer dan Elektronika, FMIPA UGM \\ ${ }^{2}$ Jurusan Ilmu Komputer dan Elektronika, FMIPA UGM \\ e-mail: *11 dan_thering@yahoo.com, ${ }^{2}$ mastri.ugm@gmail.com
}

\begin{abstract}
Abstrak
Biola merupakan alat musik berjenis tanpa fret (fretless) sehingga kualitas permainan biola sangat bergantung pada ketelitian pemain dalam memainkan setiap nadanya. Untuk para pemula proses penjarian merupakan proses yang membutuhkan waktu lama, sehingga jika kemampuan belum memadai, nada-nada yang dihasilkan dari gesekan pemain pemula sering sumbang sehingga kurang nyaman untuk didengarkan. Untuk mengatasi hal ini, diperlukan suatu alat untuk menghasilkan nada biola yang tidak sumbang ketika pemain memainkan biola secara langsung.

Sistem yang dibuat menggunakan sensor suara sebagai penangkap gelombang nada biola, mengubahnya menjadi sinyal listrik untuk diproses deteksi nilai nadanya -membaca sesuai nilai interval frekeuensi nada utama -dan memainkan data audio nada utama biola yang tidak sumbang. Proses utama dilakukan oleh mikrokontroler dengan bantuan Shield Audio. Keluaran sistem berupa nada tidak sumbang sesuai harapan yang keluar melalui speaker.

Dalam mengolah nada sumbang menjadi nada utama yang sesuai, dari uji coba menggunakan sine wave sistem menghasilkan tingkat kepreisisian 100\%. Dari uji coba menggunakan nada biola pra-rekam sistem menghasilkan tingkat kepresisian 17,33\%. Dari uji coba menggunakan nada biola dalam permainan langsung sistem menghasilkan tingkat kepresisian 10,66\%.
\end{abstract}

Kata kunci-biola, nada biola, pengoreksi nada, gelombang sinus, pencacah frekuensi

\section{Abstract}

Violin is a frteless musical instrument so that carefulness of the player affects the tone quality. For begineers, it tooks a lot of time for fingering process, so if they are not skillfull enough it will generate many out-of-tune pitches which uncomfortable to be heard. For clearing this issue, it needs an equipment for generating in-tune pitches while the violinist is playinglive.

System is made using sound sensor for receiving the wave of the violin, turned it out to electric signal and then detecting its pitch value - reading it as the interval of the main frequency - and then playing desired in-tune audio data of violin tones. The main process is done by microcontroller supported by audio shield. The output is in-tune audio data which played through speaker.

System achieved 100\% accuracy while using pure sinusoid wave tones for testing. System achieved 17,33\% accuracy while using pre-recorded violin tones for testing. System achieved 10,66\% accuracy while using live-played violin tones for testing.

Keywords - violin, violin pitch, pitch correction, sinusoid wave, frequency counter 


\section{PENDAHULUAN}

U ualitas suara yang dihasilkan biola sangat bergantung pada tingkat kemampuan pemainnya. K Pada pemain biola pemula atau amatir, kualitas suara dari permainan biola yang dihasilkan kerap kali sumbang sehingga performa musik kurang maksimal saat ditampilkan baik untuk dinikmati sendiri atau dengan orang lain. Penalaan nada merupakan hal yang mendasar dalam memainkan alat musik akustik [1] terutama pada alat musik gesek ini.

Perlu diterapkan suatu teknologi dimana nada yang dihasilkan oleh pemain biola tidak terdengar sumbang dan lebih nyaman didengarkan. Banyak riset mengenai pengolahan sinyal suara terutama untuk suara manusia/ vokal seperti yang dilakukan oleh [2], yang membuat pengoreksi nada untuk vokal menggunakan PC dan mikrofon sebagai penerima suara, suara akan direkam terlebih dahulu dan setelahnya akan dikoreksi nadanya, oleh karena itu proses pengoreksian ini bersifat tidak real-time dan tidak dapat digunakan untuk performa vokal secara langsung. Maka dari itu, penelitian ini akan merancang bangun sistem untuk permainan biola langsung yang akan mendeteksi dan mengoreksi nada secara otomatis

\section{METODE PENELITIAN}

\subsection{Analisa Sistem}

Bagaimana merancang alat pengoreksi nada pada biola secara langsung menggunakan mikrokontroler. Variasi yang dilakukan pada pengujian sistem dengan berbagai macam nada masukan berupa gelombang sinus, rekaman suara biola, dan permainan biola secara langsung.

\subsection{Arsitektur Sistem}

Arsitektur sistem yang dipakai menggunakan sebuah mikrokontroler, shield-audio, sensor suara piezo, dan spekaer. Sistem yang dirancang untuk penelitian ini merupakan suatu sistem yang dapat membaca nilai nada sumbang, mengelompokkannya dalam nilai nada utama, dan mengeluarkan suara nada utama melalui pengeras suara. Diagram blok sistem secara keseluruhan ditunjukkan pada Gambar 1.

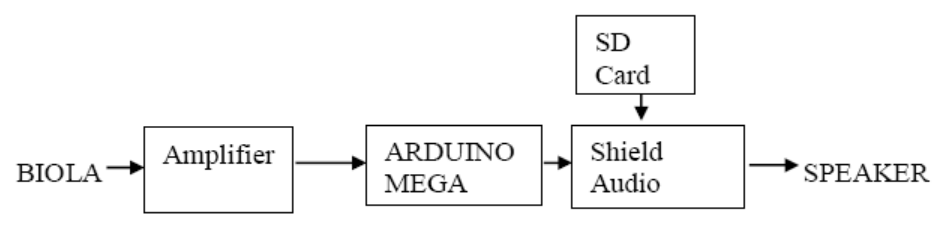

Gambar 1 Diagram Blok Sistem Keseluruhan

Sistem secara keseluruhan terdiri dari perangkat keras dan perangkat lunak. Perangkat lunak merupakan program dalam bahasa pemrograman $\mathrm{C}++$ yang diunduh ke dalam mikrokontroler. Nada yang masuk dibaca nilainya melalui pustaka pencacah frekuensi, dikelompokkan ke dalam intervalnya, memanggil data audio yang tersimpan di database.

\subsection{Metode yang digunakan}

Metode yang digunakan adalah pencecah frekuensi dalam pembacaan nilai gelombang sebagai dasar pengelompokan interval nada sumbang, dan pemanggilan data suara dari database pada memori eksternal. Pemrosesan utama bekerja di dalam mikrokontroler Arduino Mega 2560 dan shield audio sebagai pendukung.

IJEIS Vol. 6, No. 1, April 2016 : 59-68 


\subsection{Implementasi Sistem}

Implementasi perangkat keras terdiri dari Mikrokontroler Arduino Mega 2560, Shield Audio beserta kartu SD, sensor suara piezo, rangkaian penguat, dan pengeras suara, yang dapat dilihat pada Gambar 2.

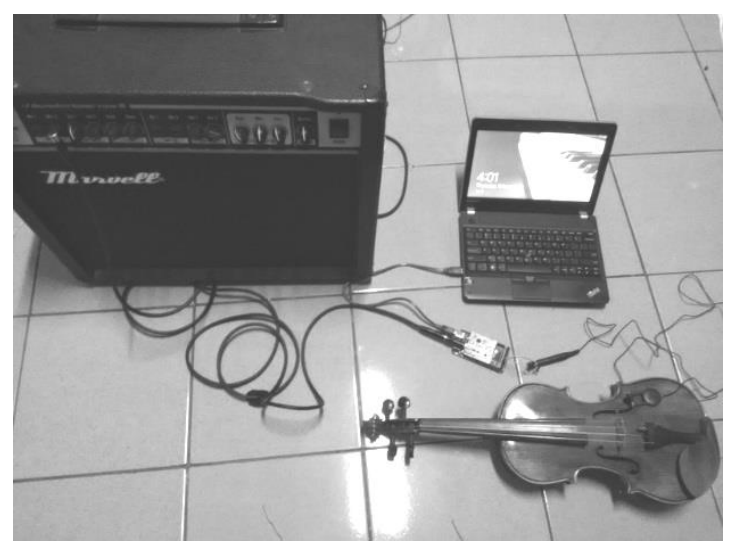

Gambar 2 Penampakan Sistem Keseluruhan

Pada perangkat lunak digunakan dua metode pengoreksian. Pertama, penghitungan nilai nada masukan (frequency counting). Sinyal masukan dalam bentuk digital dipersiapkan, disaring, dan diekstraksi. Pada tiap segmen dilakukan pengambilan sampel frekuensi setiap $100 \mathrm{~ms}$ sehingga diperoleh frekuensi utamanya untuk tiap memori. Kemudian, penentuan nilai nada (pitch detecting). Hasil penghitungan nada pada setiap siklus $100 \mathrm{~ms}$ berulang diketahui lalu dilakukan penganalisaan sesuai fungsi untuk menentukan kelompak nada yang nilainya sudah diketahui dengan cara menilik nilai frekuensi tersebut ke dalam rentang nilai frekuensi yang sesuai untuk nada fundamental yang telah ditentukan. Sistem akan memainkan nada sesuai dengan nada dimana frekuensi nada masukan tersebut berada pada rentang nada tersebut.

Permainan biola secara langsung ditangkap suaranya menggunakan sensor piezo yang ditempel pada badan biola. Gelombang akan diperbesar kekuatannya melalui rangkaian amplifier suapaya dapat dengan mudah dibaca oleh pencacah frekuensi pada mikrokontroler. Nilai pembacaan frekuensi ini secara dinamis dapat dimonitor melalui compiler Arduino IDE pada komputer. Nilai nada yang terbaca akan menyesuaikan terhadap nilai interval nada sesuai dengan algoritma pemrograman (dalam bahasa $\mathrm{C}++$ ) yang telah diunduh. Sistem menggunakan shield audio sebagai penyimpan database dalam modul kartu memori, dan juga sebagai penghubung hasil/ keluaran ke pengeras suara. Kartu memori menyimpan data audio masing masing nada dari G3 hingga C6 dalam format ekstensi MP3. Tiap interval akan memanggil data audio yang relevan dari database yang tersimpan di dalam kartu memori pada shield audio. Data audio yang terpanggil akan dimainkan secara otomatis dan dikeluarkan melalui pengeras suara. Alur kerja program dari awal dapat dilihat pada Gambar 3. 


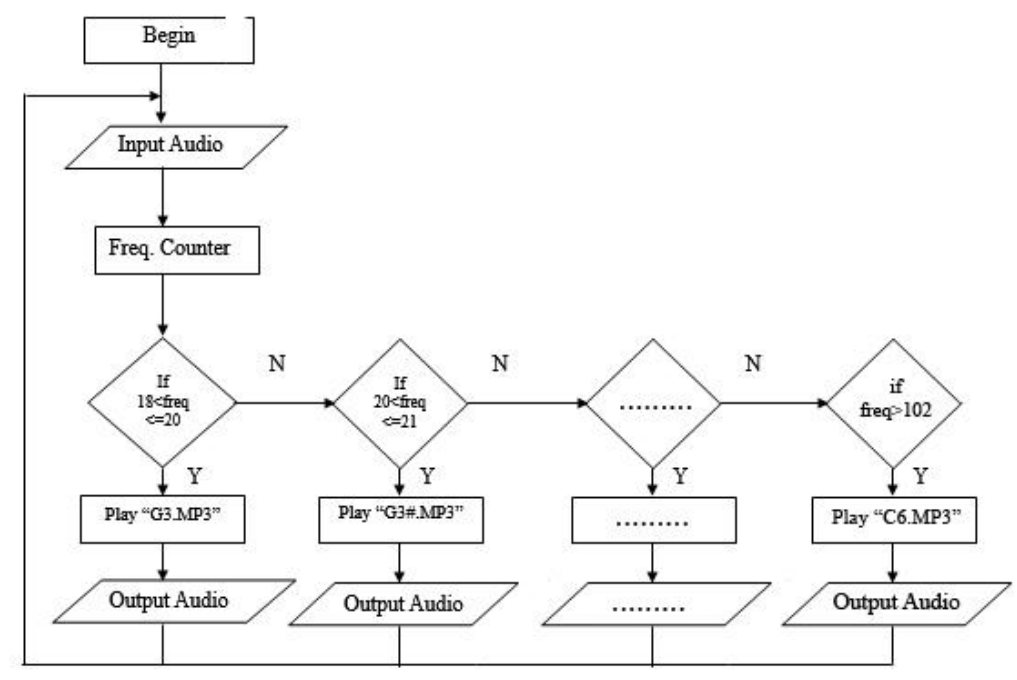

Gambar 3 Flow Chart Program

Sistem pengoreksi yang dibuat adalah sistem pengoreksi dengan konsep keluaran berupa nada biola pra-rekam (sampel) yang berintonasi bagus dan bernilai pada dan di sekitar nilai frekuensi fundamental nada terkait. - mengigat bahwa biola adalah alat musik fretless sehingga kemungkinan untuk memainkan nada pada satu titik nilai frekuensi (sesuai kaidah teori) secara repetitif akan sangat mustahil pada praktiknya. Nada-nada sampling ini disimpan pada kartu memori ( $S D$ card) dan disematkan pada slot kartu memori yang sudah tersedia pada Shield Audio.

Nada audio keluaran ini diperolah melalui bantuan perangkat lunak untuk mengkomposisi lagu yaitu Sibelius versi 7. Dengan metode notasi balok virtual, tiap nada dibuat secara kromatis dari nada G3 hingga C6 dalam moda suara Acoustic Violin/ biola akustik yang terdengar cukup nyata kemudian dikonversi dalam format MP3. Nada audio keluaran berdurasi cukup singkat yaitu 0,5 detik merujuk pada sistem yang bekerja secara siklus dalam hitungan waktu $100 \mathrm{~ms}$, sehingga nada keluaran yang terbentuk merupakan pengulangan nada 0,5 detik tersebut secara repetitif - saling menyambung - yang diharapkan dapat berulang dengan sangat cepat untuk mendapatkan efek nada panjang yang halus. Hal ini juga untuk mengantisipasi keefektifan keluaran dari berbagai jenis tempo nada pada lagu yang dimainkan.

\section{HASIL DAN PEMBAHASAN}

\subsection{Pengujian Frequency Counter}

Pengujian ini dilakukan dengan mendeteksi gelombang masukan yang bernilai pasti (fundamental pitch) berupa gelombang sinus (sinusoidal wave) berdurasi 10 detik (10 s) yang dimainkan melalui komputer dan mejadikannya sebagai sinyal masukan. Tiap nilai gelombang sinus merepresentasikan nilai-nilai frekuensi nada biola dari nada G3 $(196,00 \mathrm{~Hz})$ hingga C6 $(1046,50 \mathrm{~Hz})$. Hasil pengujian penghitungan frekuensi dengan gelombang sinus ini akan dijadikan acuan untuk menghitung nilai rentang untuk masing-masing nada fundamental dari nada G3 hingga C6 pada kode program utama.

Data audio dimainkan satu perstatu melalui komputer. Dengan melalui output/ earphone jack pada komputer, sinyal dikeluarkan kemudian diamplifikasi lewat rangkaian penguat dan menjadikannya sinyal masukan ke mikrokontroler, lalu diproses dalam program penghitungan frekuensi yang sudah diunggah ke dalam sistem Arduino. Setelah sinyal diproses, nilai hasil 
pembacaan frekuensi sinyal sinus diamati lewat Serial Monitor pada interface Arduino 1.06. Penghitungan berupa siklus berulang dengan kecepatan 100ms per siklusnya dan serial monitor menampilkan nilai hasil pembacaan tiap siklus.

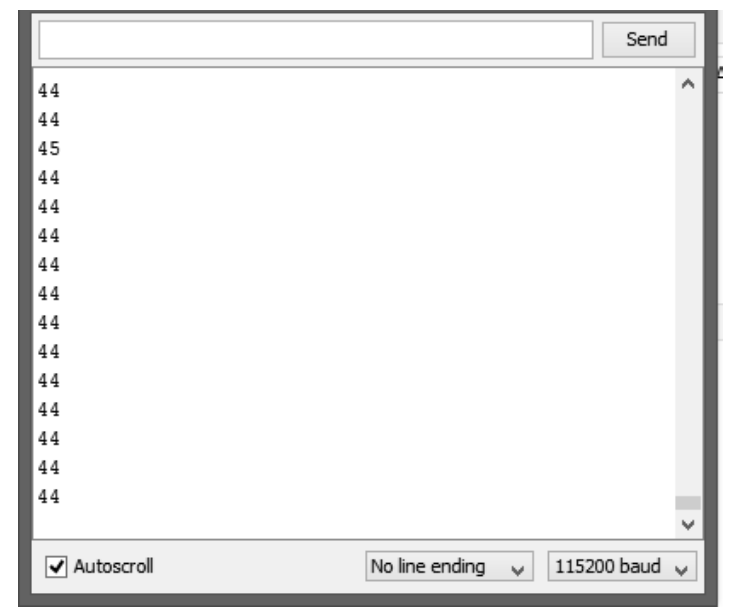

Gambar 4 Serial Monitor Arduino Ketika Menampilkan Nilai Gelombang Sinus Nada A4 (440 Hz)

Seperti yang terlihat pada Gambar 4, Serial Monitor menampilkan nilai pembacaan bernilai $1 \times 10^{-1}$ tanpa angka di belakang koma jika dibandingkan dengan nilai frekuensi yang seharusnya. Jika frekuensi asli bernilai $440 \mathrm{hz}$, maka serial monitor akan menampilkan nilai pembacaan 44. Pengambilan dua digit pertama ini dikarenakan sistem mebutuhkan waktu 100 ms sebagai Gate Time. Jika nilai gate time ini dinaikkan, akan berdampak pada waktu pemrosesan yang lebih lama namun akan menampilkan nilai frekuensi dalam nilai yang lebih presisi. Karena sistem membutuhkan pemrosesan yang relatif cepat, maka nilai gate time dipertahankan pada nilai 100 dengan nilai hasil pembacaan frekuensi rata-rata oleh sistem tetap dapat dianggap cukup presisi $(97,26 \%)$. Berikut ini adalah Tabel 1 yang menunjukkan hasil pembacaan gelombang sinus oleh sistem dari nada G3 $(196,00 \mathrm{~Hz})$ hingga C5 $(1046,50 \mathrm{~Hz})$ beserta nilai sumbang kurang(-) dan sumbang lebih (+) nya secara acak.

Tabel 1 Hasil pengujian fungsional pembacaan frekuensi (frequency counter)

\begin{tabular}{|c|c|c|c|c|c|c|c|}
\hline $\begin{array}{l}\text { Nada } \\
\text { Musik }\end{array}$ & $\begin{array}{c}\text { Nada } \\
\text { pengujian }\end{array}$ & $\begin{array}{l}\text { Frek. } \\
\text { Sinusoid } \\
\mathrm{F}(\mathrm{Hz})\end{array}$ & $\begin{array}{c}\text { Nilai } \\
\text { terbaca } \\
\mathrm{f}^{\prime}\end{array}$ & $\begin{array}{c}\text { Nilai } \\
\text { dominan } \\
\left(\mathrm{f}^{\prime} \times 10^{1}\right)\end{array}$ & $\begin{array}{c}\text { Error } \\
(\mathrm{Hz})\end{array}$ & $\begin{array}{c}\text { Error } \\
(\%)\end{array}$ & $\begin{array}{c}\text { Akurasi } \\
(\%)\end{array}$ \\
\hline 1 & 2 & 3 & 4 & 5 & 6 & 7 & 8 \\
\hline \multirow{3}{*}{ G3 } & G3- & 195,00 & $19 / 20$ & 190 & 5,00 & 2,56 & 97,44 \\
\hline & G3 & 196,00 & $19 / 20$ & 200 & 4,00 & 2,04 & 97,96 \\
\hline & G3+ & 198,00 & 20 & 200 & 2,00 & 1,01 & 98,99 \\
\hline \multirow{3}{*}{ G3\# } & G3\#- & 206,00 & $20 / 21$ & 210 & 4,00 & 1,94 & 98,06 \\
\hline & G3\# & 207,65 & 21 & 210 & 2,35 & 1,13 & 98,87 \\
\hline & G3\#+ & 213,00 & 21 & 210 & 3,00 & 1,41 & 98,59 \\
\hline$\ldots \ldots$ & $\ldots \ldots \ldots$ & $\ldots \ldots \ldots$ & ......... & $\ldots \ldots \ldots$ & $\ldots \ldots .$. & $\ldots \ldots .$. & $\ldots \ldots .$. \\
\hline \multirow{3}{*}{ C6 } & C6- & 1034,00 & 103 & 1030 & 3,00 & 0,29 & 99,71 \\
\hline & C6 & 1046,50 & $104 / 105$ & 1050 & 3,50 & 0,33 & 99,64 \\
\hline & C6+ & 1057,00 & $105 / 106$ & 1060 & 3,00 & 0,28 & 99,72 \\
\hline \multicolumn{7}{|c|}{ Akurasi rerata dalam mendeteksi nilai frekuensi } & 97,26 \\
\hline
\end{tabular}


Berdasarkan hasil pengujian sistem pembacaan nilai frekuensi fundamental tiap nada berbasis sinyal sinus, diketahui nahwa makin tinggi suatu nada, maka makin lebar selisih antar nada sehingga hasil pembacaan frekuensi oleh sistem dari awal oktaf ke-tiga cukup dekat satu sama lain (hanya berselisih satu nilai) kemudian melebar hingga oktaf ke-lima (hingga selisih 6 nilai). Hal ini sesuai dengan dasar teori penghitungan nilai frekuensi nada bahwa suatu nada yang sama akan bernilai dua kali lipat pada oktaf selanjutnya. Pelebaran nilai selisih yang terbaca pada sistem akan memengaruhi rentang nada untuk tiap nada fundamental yang kemudian akan dimasukkan dalam kode program utama.

\subsection{Pengambilan Nilai Rentang Tiap Nada}

Karena selisih nilai nada yang terbaca pada oktaf ke-3 cukup dekat, maka dipilih rentang nada yang juga sempit namun rentang akan makin melebar seiring dengan naiknya oktaf, nilai nada, selisih nilai nada. Nilai pada rentang yang melebar dipilih berdasarkan nilai tengah pada selisih antara satu nilai dengans satu nilai sebelum dan satu nilai setelahnya. Hal ini lah yang akan mendasari nilai toleransi sumbang kurang dan sumbang lebih. untuk tiap nada ketika input berupa suara biola yang dimainkan. Jika nilai nada sumbang berada di bawah nilai fundamental, maka termasuk sumbang kurang Jika nilai sumbang berada di atas nilai fundamental, maka termasuk sumbang lebih. Sumbang kurang dan sumbang lebih inilah yang kemudian akan dibaca oleh sistem sesuai pengelompokan nilai toleransi sesuai pada Tabel 2 , diikuti dengan pemanggilan data audio yang berkaitan. Pengambilan nilai rentang ini yang akan menentukan data audio mana yang akan dimainkan untuk tiap nada yang diproses oleh sistem. Karena sifat nada utama yang jika makin besar nilai frekuensi nada maka makin besar nilai jarak antar nadanya, maka interval tiap nada yang diperoleh akan makin melebar nilai intervalnya, sehingga interval nada C6 akan lebih lebar daripada nada-nada di bawahnya dan interval nada G3 paling sempit daripada nada-nada di atasnya.

Tabel 2 Nilai rentang tiap nada yang ditentukan berdasarkan hasil pembacaan nilai dan korelasinya dengan data audio.

\begin{tabular}{|c|c|c|c|c|}
\hline Nada Musik & $\begin{array}{c}\text { Frekuensinya } \\
(\mathrm{Hz})\end{array}$ & $\begin{array}{c}\text { Nilai terbaca } \\
\mathrm{f}^{\prime}\end{array}$ & $\begin{array}{c}\text { Nilai rentang } \\
\text { yang dipilih } \\
\text { terhadap f }\end{array}$ & $\begin{array}{c}\text { Data audio } \\
\text { yang nantinya } \\
\text { dikeluarkan } \\
\text { sistem }\end{array}$ \\
\hline G3 & 196,00 & $19 / 20$ & $18<\mathrm{f}^{\prime}<=20$ & G3.mp3 \\
\hline G3\# & 207,65 & 21 & $20<\mathrm{f}^{\prime}<=21$ & G3\#.mp3 \\
\hline A3 & 220,00 & 22 & $21<\mathrm{f}^{\prime}<=22$ & A3.mp3 \\
\hline A3\# & 233,08 & 23 & $22<\mathrm{f}^{\prime}<=23$ & A3\#.mp3 \\
\hline B3 & 246,94 & $24 / 25$ & $23<\mathrm{f}^{\prime}<=25$ & B3.mp3 \\
\hline C4 & 261,63 & 26 & $25<\mathrm{f}^{\prime}<=26$ & C4.mp3 \\
\hline C4\# & 277,18 & $27 / 28$ & $26<\mathrm{f}^{\prime}<=28$ & C4\#.mp3 \\
\hline$\ldots \ldots .$. & $\ldots \ldots \ldots$. & $\ldots \ldots$. & $\ldots \ldots$. & $\ldots \ldots$. \\
\hline C6 & 1046,50 & $104 / 105$ & $102<\mathrm{f}^{\prime}$ & C6.mp3 \\
\hline
\end{tabular}

\subsection{Pengujian Sistem Koreksi Nada Menggunakan Nada Murni (Gelombang Sinus)}

Pengujian ini dilakukan untuk menguji tingkat keakuratan sistem dalam memproses sinyal sinus fundamental, sumbang kurang (-), dan sumbang (+) secara satu per-satu berdasarkan interval nada yang sudah ditentukan sebelumnya pada sistem untuk menjadi nada keluaran audio MP3 yang sesuai, sekaligus mengamati nada keluaran audio MP3 tersebut.

IJEIS Vol. 6, No. 1, April 2016 : 59-68 
Tabel 3 Hasil Pengoreksian Nilai Frekuensi Nada pada Gelombang Sinus

\begin{tabular}{|c|c|c|c|c|}
\hline $\begin{array}{c}\text { Nada } \\
\text { gelombang } \\
\text { sinus yang diuji }\end{array}$ & $\begin{array}{c}\text { Nilai } \\
\text { frekuesi } \\
(\mathrm{Hz})\end{array}$ & Nilai terbaca & $\begin{array}{c}\text { Data audio } \\
\text { yang } \\
\text { dikeluarkan } \\
\text { sistem }\end{array}$ & Status \\
\hline 1 & 2 & 3 & 4 & 5 \\
\hline G3- & 195,00 & $19 / 20$ & G3 & Terkoreksi \\
\hline G3 & 196,00 & $19 / 20$ & G3 & Terkoreksi \\
\hline G3+ & 198,00 & 20 & G3 & Terkoreksi \\
\hline G3\#- & 206,00 & $20 / 21$ & G3\# & Terkoreksi \\
\hline G3\# & 207,65 & 21 & G3\# & Terkoreksi \\
\hline G3\#+ & 213,00 & 21 & G3\# & Terkoreksi \\
\hline$\ldots \ldots .$. & $\ldots \ldots \ldots$ & $\ldots \ldots \ldots$ & $\ldots \ldots .$. & $\ldots \ldots .$. \\
\hline C6- & 1034,00 & 103 & C6 & Terkoreksi \\
\hline C6 & 1046,50 & $104 / 105$ & C6 & Terkoreksi \\
\hline C6+ & 1057,00 & $105 / 106$ & C6 & Terkoreksi \\
\hline Akurasi rerata dalam mengoreksi nilai frekuensi nada & $100 \%$ \\
\hline
\end{tabular}

Berdasarkan Tabel 3 diperoleh hasil keakuratan sistem dengan pengujian menggunakan gelombang sinus adalah 100\%. Pada hasil keluaran audio MP3 yang diamati secara langsung melalui speaker dihasilkan nada terkoreksi yang repetitif mengikuti durasi nada yang dikoreksi, namun tidak terdengar cukup halus dikarenakan terdapat jeda yang cukup nampak antara hasil audio MP3 yang satu dengan yang lain. Hal ini dikarenakan siklus bekerja pada siklus 100ms. Nilai siklus ini merupakan nilai periode yang ditentukan untuk mencuplik frekuensi yang akan diproses. Nilainya akan berpengaruh pada kecepatan proses dan keakuratan pembacaan frekuensi. Untuk mendapatkan hasil keluaran yang halus, maka dibutuhkan kecepatan kerja yang lebih cepat dengan nilai siklus lebih rendah. Namun menurunnya nilai siklus akan menurunkan keakuratan pembacaan frekuensi. Sebaliknya, jika nilai siklus dinaikkan maka kecepatan kerja lebih lambat namun akan menaikkan keaukaratan pembacaan frekuensi.. Maka dari itu, dipilih siklus kerja proses pada gate time 100ms sebagai nilai siklus terbaik.

\subsection{Pengujian Sistem dengan Nada Sumbang pada Nada Biola Pra-Rekam}

Pengujian ini untuk memastikan sistem keseluruhan dapat berjalan dengan baik dengan hasil sesuai yang diinginkan. Hasil berupa nada audio MP3 yang dimainkan (play) oleh sistem sesuai korelasinya dengan nilai frekuensi masukan (sumbang) pra-rekam kemudian sinyal dibaca sistem dan dikelompokkan sesuai rentang nilai yang telah diperoleh.

Pengujian akan menggunakan sampel lagu suara biola berpola tangga nada $\mathrm{C}$ mayor (14 buah nada sumbang) dua oktaf yang sudah direkam sebelumnya (pra-rekam) menggunakan biola akustik dan piezo pickup sebagai sensor suaranya.Tanpa harus mengetahui nilai aktual frekuensi tiap nada sumbang yang dimainkan pada lagu pra-rekam, akan diuji seberapa akurat sistem dapat mengatasi tiap nada sumbang pada lagu. Lagu akan diuji sebanyak 5 kali, dimainkan melalui pemutar lagu di laptop kemudian hasilnya diamati melalui dua aspek : secara visual melalui serial monitor Arduino IDE 1.06 dan secara audio melalui output MP3 ke speaker aktif. Dapat diamati pada Tabel 4, bahwa ketika sistem diuji dengan sinyal biola asli pra-rekam, serial monitor menampakkan nilai yang beragam sehingga untuk tiap nada prerekam saat dimainkan menghasilkan beragam nada MP3 keluaran. Sistem membaca sinyal masukan dan terjadi banyak kesalahan pada hasil pengoreksian. Oleh karena itu untuk memudahkan pengamatan telah diambil nada hasil koreksi pertama pada tiap nada yang dimainkan pada masing percobaan, sehingga dihasilkan nilai rata - rata tingkat keberhasilan sistem dalam mengoreksi nada biola pra-rekam dalam lagu $=17,33 \%$. 
Tabel 4 Hasil pengoreksian nada biola pra-rekam pada lagu tangga nada $\mathrm{C}$ mayor 2 oktaf

\begin{tabular}{|c|c|c|c|c|c|c|}
\hline $\begin{array}{c}\text { Nada } \\
\text { ke- }\end{array}$ & $\begin{array}{l}\text { Nada yang } \\
\text { diharapkan }\end{array}$ & $\begin{array}{c}\text { Perc. } \\
1\end{array}$ & $\begin{array}{l}\text { Perc. } \\
2\end{array}$ & $\begin{array}{c}\text { Perc. } \\
3\end{array}$ & $\begin{array}{c}\text { Perc. } \\
4\end{array}$ & $\begin{array}{l}\text { Perc. } \\
5\end{array}$ \\
\hline 1 & C4 & D4 & C4 & F4\# & $\mathrm{C} 4$ & D4 \\
\hline 2 & D4 & G5 & B5\# & G5 & B5\# & D4 \\
\hline 3 & E4 & G3\# & C6 & C6 & G3\# & C6 \\
\hline 4 & F4 & E4 & E4 & B5 & C6 & C6 \\
\hline 5 & G4 & G5\# & B5 & B5 & G5\# & B5 \\
\hline 6 & A4 & $\mathrm{A} 4$ & $\mathrm{~A} 4$ & C6 & D5\# & A4 \\
\hline 7 & B4 & G5\# & G5 & C5\# & A4 & A4 \\
\hline 8 & $\mathrm{C} 5$ & $\mathrm{C} 5$ & D5\# & D5 & D5\# & G5 \\
\hline 9 & D5 & B4 & C4 & C6 & A4 & G5\# \\
\hline 10 & E5 & G3\# & E5 & C6 & A3 & C6 \\
\hline 11 & F5 & B5 & D5\# & $\mathrm{C} 5$ & B4 & B4 \\
\hline 12 & G5 & G5 & G5 & G5 & C6 & C6 \\
\hline 13 & A5 & A4\# & A4\# & C6 & A5 & C6 \\
\hline 14 & B5 & G4\# & G4\# & B5 & C6 & C6 \\
\hline 15 & C6 & E5 & E5 & F5 & E5 & F5 \\
\hline & $\begin{array}{l}\text { ingkat } \\
\text { rhasilan }\end{array}$ & $\begin{array}{c}3 / 15= \\
20,00 \%\end{array}$ & $\begin{array}{c}4 / 15= \\
26,66 \%\end{array}$ & $\begin{array}{r}2 / 15= \\
13,33 \%\end{array}$ & $\begin{array}{c}2 / 15= \\
13,33 \%\end{array}$ & $\begin{array}{c}2 / 15= \\
13,33 \%\end{array}$ \\
\hline
\end{tabular}

\subsection{Pengujian Sistem dengan Nada Sumbang pada Nada Biola yang Dimainkan Langsung}

Pengujian ini untuk memastikan sistem keseluruhan dapat berjalan dengan baik dengan hasil sesuai yang diinginkan. Hasil berupa nada audio MP3 yang dimainkan (play) oleh sistem sesuai korelasinya dengan nilai frekuensi masukan (sumbang) yang dimainkan dengan biola secara langsung kemudian sinyal dibaca sistem dan dikelompokkan sesuai rentang nilai yang telah diperoleh.

Pengujian akan menggunakan permainan biola secara langsung oleh pemain biola dalam sebuah lagu berupa tangga nada $\mathrm{C}$ mayor dua oktaf menggunakan biola akustik dan piezo pickup sebagai sensor suaranya. Tanpa harus mengetahui nilai aktual frekuensi tiap nada sumbang yang dimainkan secara langsung, akan diuji seberapa akurat sistem dapat mengatasi tiap nada sumbang pada permainan lagu. Lagu yang identik akan diuji sebanyak 5 kali, kemudian hasilnya diamati secara visual melalui serial monitor Arduino IDE 1.06 dan secara audio melalui output MP3 ke speaker aktif.

Dapat dilihat pada Tabel 5 bahwa ketika sistem diuji dengan sinyal biola asli yang dimainkan secara langsung oleh seorang pemain biola, serial monitor menampakkan nilai yang beragam dan acak sehingga untuk tiap nada yang dimainkan menghasilkan nada MP3 keluaran yang juga beragam dan acak. Sistem membaca sinyal masukan dan terjadi banyak kesalahan pada hasil pengoreksian. Oleh karena itu untuk memudahkan pengamatan telah diambil nada hasil koreksi pertama pada tiap nada yang dimainkan pada masing percobaan. Karena permainan pemain biola antar satu percobaan satu dengan percobaan lain tidak sama persis, maka hasil untuk tiap percobaan terdapat beberapa perbedaan yang cukup signifikan, sehingga dihasilkan nilai rata - rata tingkat keberhasilan sistem dalam mengoreksi nada biola yang memainkan lagu secara langsung $=10,66 \%$, lebih rendah daripada tingkat keberhasilan pengujian menggunakan nada biola pra-rekam. 
Tabel 5 Hasil pengoreksian nada biola yang dimainkan secara langsung pada lagu tangga nada C mayor 2 oktaf

\begin{tabular}{|c|c|c|c|c|c|c|}
\hline $\begin{array}{c}\text { Nada } \\
\text { ke- }\end{array}$ & $\begin{array}{c}\text { Nada yang } \\
\text { diharapkan }\end{array}$ & $\begin{array}{c}\text { Perc. } \\
1\end{array}$ & $\begin{array}{c}\text { Perc. } \\
2\end{array}$ & $\begin{array}{c}\text { Perc. } \\
3\end{array}$ & $\begin{array}{c}\text { Perc. } \\
4\end{array}$ & $\begin{array}{c}\text { Perc. } \\
5\end{array}$ \\
\hline 1 & C4 & D4 & G5 & A4 & C6 & C6 \\
\hline 2 & D4 & G4 & A4 & A4 & B5 & G4\# \\
\hline 3 & E4 & G3 & C5\# & B5 & A5 & A5 \\
\hline 4 & F4 & A5\# & C4 & A4 & F4 & A5\# \\
\hline 5 & G4 & A4 & B5 & F5 & B4 & G4 \\
\hline 6 & A4 & A5\# & A4 & A5 & A5 & G5 \\
\hline 7 & B4 & A5\# & A5\# & B4 & F5 & B4 \\
\hline 8 & C5 & G3 & A5 & E5 & G4\# & G4 \\
\hline 9 & D5 & G4\# & D5 & A5 & B4 & B4 \\
\hline 10 & E5 & F4 & G5\# & A5 & B5 & C6 \\
\hline 11 & F5 & F5 & F4\# & A4 & C6 & C6 \\
\hline 12 & G5 & C4 & A5 & A5\# & B5 & C5 \\
\hline 13 & A5 & D5\# & A5 & E5 & F5 & B5 \\
\hline 14 & B5 & B5 & C6 & A4 & A5\# & B4 \\
\hline 15 & C6 & A5 & A5\# & C6 & D5 & A5 \\
\hline \multicolumn{2}{|l|}{ Tingkat Keberhasilan } & $2 / 15=$ & $3 / 15=$ & $1 / 15=$ & $1 / 15=$ & $1 / 15=$ \\
& & $13,33 \%$ & $20,00 \%$ & $6,66 \%$ & $6 ., 66 \%$ & $6,66 \%$ \\
\hline
\end{tabular}

Ketidak akuratan hasil yang cukup berarti ini disebabkan oleh beberapa aspek. Pada awal pengujian, input adalah berupa gelombang sinusoid. Gelombang sinus ini bersifat bersih, stabil, dan konstan di nilainya, sangat efektif untuk digunakan sebagai media/ objek pengamatan sehingga akan menghasilkan nilai yang sangat presisi. Pada pengujian selanjutnya (baik secara pra-rekam maupun permainan langsung) input adalah berupa gelombang suara yang diterima sensor suara piezo dari biola. Gelombang alami ini bersifat tidak stabil dengan frekuensi-frekuensi lain (frekuensi harmonik) yang menempel pada frekuensi fundamental. Frekuensi harmonik inilah yang membuat sinyal sulit dibaca dengan lugas oleh sistem sehingga menghasilkan hasil akhir yang tentatif dan tidak akurat.

\section{KESIMPULAN}

Kesimpulan yang diambil dari penelitian ini adalah sebagai berikut :

1. Telah dibuat sebuah alat untuk mengoreksi nada pada biola menggunakan mikrokontroler ATMega 2560.

2. Metode yang digunakan dalam rancangan tidak dapat memenuhi fungsi yang diinginkan sehingga sistem yang bekerja tidak dapat mencapai tujuan.

3. Hasil pengujian sistem dengan nada biola yang kurang akurat disebabkan karena terdapat frekuensi-frekuensi harmonik yang menempel pada frekuensi utama nada biola dan menyebabkan pembacaan frekuensi tidak akurat (terganggu).

\section{SARAN}

Untuk memperbaiki tingkat akurasi sitem ini,dapat ditambahkan perancangan sistem yang dapat memilah frekuensi harmonik dengan frekuensi utama, dan untuk memperbaiki kualitas keluaran dapat menggunakan pemroses yang memiliki kecepatan lebih tinggi daripada mikrokontroler ATMega 2560. 


\section{UCAPAN TERIMA KASIH}

Penulis mengucapkan terima kasih yang sebesar - besarnya kepada:

1. Teman-teman anggota GMCO yang telah mendukung penelitian ini.

2. Pendiri, Pembina, dan Penggemar GMCO yang menjadi inspirasi.

\section{DAFTAR PUSTAKA}

[1] Chandra, R., 2010, Rekognisi Berbasis Audio dengan Pendekatan Alih Ragam Gelombang Singkat Diskrit.

[2] Jensen, Nikolas Borrel., 2009, Real Time Pitch Correction, Technical University of Denmark,Copenhagen. 